\title{
Das confluências e influências entre teatro, política e engajamento
}

\section{About confluences and influences of theater, politics and engagement \\ Marco Anselmo Vasques ${ }^{1}$ \\ Rubens da Cunha ${ }^{2}$}




\section{Resumo}

Amparados, entre outros, nos pensadores Jacques Rancière, Hans-Thies Lehmann, Maria Tereza Kuhner, apresentamos algumas das principais ideias sobre as relações entre teatro, política e estética. A segunda parte do artigo é dedicada à questão do engajamento, pois se trata de um tema que teve forte presença no teatro brasileiro. Os aspectos teóricos do engajamento advém do pensamento de Jean Paul-Sartre e Paul-Louis Landsberg.

Palavras-chave: Teatro Político; Estética; Engajamento

\section{Abstract}

In this article, we present some of main ideas about the intertwined relation among theater, politics and aesthetics. Such ideas are developed based on authors such as Jacques Rancière, HansThies Lehmann, Maria Tereza Kuhner and others. We also dedicate attention to the issue of engagement, once it is a topic that had a great presence in the Brazilian theater. The theoretical aspects of engagement comes from thoughts of Jean Paul Sartre and Paul- Louis Landsberg.

Keywords: Politcal Theater; Aesthetics; Engagement
ISSN: 1414.5731

E-ISSN: 2358.6958 


\section{Teatro político: uma possível tautologia}

As díades arte e moral, estética e política, forma e conteúdo, verdadeiro ou falso, real ou ficcional estão em constantes fluxos e interações. Aristófanes, em As Rãs, inicia um debate em que centraliza as posições divergentes sobre a função do poeta e da arte, colocando em confronto as defesas dos dramaturgos Eurípedes e Esquilo. O primeiro atribui à arte e ao poeta a capacidade de apresentar a realidade desconsiderando aspectos morais e éticos, já o segundo, em linha oposta, coloca o poeta e sua arte com arautos das finalidades moralizantes atinentes ao seu contexto social, político e histórico. Tudo balizado, ainda que subliminarmente, por uma constante oposição entre o real e o ficcional, entre o estético e o político. Nesta roda da história do conhecimento e da disputa por instaurar uma instância de verdade, nem mestres e discípulos se entendem. Platão, por exemplo, atribui ao conceito de mimese valor negativo, ao passo que Aristóteles, em sua Poética, vai lhe garantir lugar auspicioso na sua teoria sobre a tragédia. Vamos aqui discutir estas aparentes dicotomias, tomando como ponto de partida alguns problemas apontados por artistas e pensadores do século XX que se debruçaram sobre o teatro como ação política.

Bernard Dort (1971, p. 267), num ensaio sobre o teatro político, já no primeiro parágrafo estabelece que esta expressão é imprecisa, ou até mesmo obscura. Tratarse-ia de uma tautologia, pois para ele todo grande teatro é, por definição, político. Assim, política e teatro sempre andaram, historicamente, imbricados, muitas vezes fundindo-se num corpo só. Num texto sobre história, política e teatro, o professor Adalberto Paranhos reafirma a tautologia prenunciada por Dort, pois "o teatro, seja autodenominado político, engajado, revolucionário ou até apolítico, é sempre político, independente da consciência que seus autores e protagonistas tenham disso" (Paranhos, 2012, p. 34). Por outro lado, Hans-Thies Lehmann (2008, p. 234) pensa o teatro político em dois sentidos: "não só das peças que se ocupam desses temas, mas também da própria escrita que está relacionada a temas políticos, de como ela é política". Para o estudioso alemão, o teatro político não é apenas aquele que trata de temas eminentemente políticos, mas, igualmente, o que adquire uma forma política. Esse conceito vem de uma frase do jovem Lukács que diz que o que é verdadeiramente social na arte é a forma. Assim, para Lehmann, a forma tem um papel preponderante quando pensamos num teatro político que não se resume a ser um transmissor de informações: todos são informados, diariamente, sobre as injustiças, os descasos, os desmandos que são perpetrados no mundo, dessa maneira a palavra político seria um índice que levaria a um engano, mesmo que válido. Tratar problemas éticos e morais em forma de fábulas, alegorias, ou mesmo com um discurso direto, para ser entendido pela maioria, não torna o teatro moral ou ético. Fazer do texto um espaço para representar as injustiças sociais não torna o texto político, ou seja, o teatro não serve para ser receptáculo da política. "O fato de se notar em uma encenação o engajamento político do diretor como pessoa, o fato de ele assumir publicamente uma posição é louvável, mas não é necessariamente diferente do que ele poderia fazer em outra profissão", diz Lehmann, desmistificando um dos ideários mais comuns dos anos de 1960: o do artista engajado, aquele que se posta tal como 
um missionário esclarecedor. Augusto Boal, em sua autobiografia, também ironiza essa ideia do teatro uma subserviência ao político. Diz Boal:

A isto chamo Síndrome Che, que tantos de nós um dia padecemos. Querer libertar escravos à força: tenho a minha verdade, sei o que é melhor para eles, então, já, façamos o que quero que façam. Sei que é certo. Vejo o que não podem ver: venham comigo, quero abrir seus olhos. Tem que ver o que vejo, pois vejo o caminho certo! As intenções, as melhores. A prática, autoritária, vinha de cima. (Boal, 2000, p. 177)

Para Lehmann (2008, p. 234), o teatro se perde quando quer ser apenas esse transmissor de informações, pois o efeito que o político causa no teatro pode, muitas vezes, ser involuntário, como algo que vai além da intenção inicial do dramaturgo. Em outro texto, Lehmann $(2009$, p. 3) é taxativo: "O teatro não pode ser um instituto de auxílio para a formação política", por isso é necessário haver um trabalho mais profundo de como se apropriar dessas informações: "política é o modo como você trabalha a percepção dessas questões. São várias formas de percepção do político que variam". Assim, para o estudioso alemão, o político "só pode aparecer indiretamente, em um ângulo oblíquo, de modo oblíquo".

Ao longo dos anos de 1960, conhecemos um teatro fortemente marcado pelas intenções políticas. Naquele período, em seu livro Teatro em Tempo de Síntese, Maria Helena Kühner dizia que

a irrupção do tempo como nova dimensão no humano, mudando a própria noção estética das coisas para outra, mais dinâmica e evolutiva, e as profundas modificações por que passou, no plano dos fatos, obrigam o homem a repensar seus valores e ideias, renovar e inovar sua ação, para obter o controle das forças e circunstâncias que sobre ele agem, mantendo-se assim dono do próprio destino. (Kühner, 1971, p. 15)

Dessa forma, no auge dos anos de 1960, um dos valores principais a serem renovados seria a revolta, o protesto. Porém, muitas seriam as diretrizes tomadas pelos artistas para pôr em prática essa renovação. Maria Helena traça uma síntese das mudanças pelas quais o teatro passou no longo transcurso entre o final do século XIX e a década de 1960. Uma dessas mudanças teria sido a decadência da burguesia e a ascensão do proletariado. O herói burguês entrou em declínio desde o fim do século

${ }^{3}$ Em 1985, logo após o fim da ditadura militar, Tom Zé no show No jardim da política, entre o canto e a declamação, também ironizava essa postura dos artistas, na canção "Classe Operária".

\author{
Sobe no palco o cantor engajado Tom Zé, \\ que vai defender a classe operária, \\ salvar a classe operária \\ e cantar o que é bom para a classe operária. \\ Nenhum operário foi consultado \\ não há nenhum operário no palco \\ talvez nem mesmo na plateia, \\ mas Tom Zé sabe o que é bom para os operários. \\ Os operários que se calem, \\ que procurem seu lugar, com sua ignorância, \\ porque Tom Zé e seus amigos \\ estão falando do dia que virá \\ e na felicidade dos operários.
}


XIX, com o predomínio da escola naturalista. Peter Szondi (2001, p. 101) afirma que o drama naturalista passou a escolher seus heróis nas camadas mais baixas da sociedade, trazendo para o palco um herói cuja força de vontade era inquebrantável, um herói engajado, impelido pela paixão, que tinha senso do coletivo, em detrimento ao "eu" ou à reflexão individual ${ }^{4}$. Dessa forma, para Szondi:

À diferença entre as camadas baixas e altas da sociedade correspondia a diferença dramatúrgica: a capacidade e a incapacidade para suster o drama. O lema naturalista, que de boa fé preconizava que o drama não era uma posse exclusiva da burguesia, ocultava a amarga constatação de que a burguesia há muito já não possuía mais o drama. (2001, p. 102)

Seguindo nessa linha de pensamento, Maria Helena Kühner (1968, p. 21) dia que, a "decadência do herói burguês representa a falência dos valores e atitudes que sempre lhe foram tradicionalmente associados" e é por esses valores que ele passa a ser atacado. O ataque também se dá por outra característica do século $\mathrm{XX}$, que seria

a tendência dos indivíduos a se associarem para fins que ultrapassam a suas capacidades individuais, trazida não só pela revolução industrial e consequente ascensão das massas, mas também pela 'planetização' do mundo e pelo desenvolvimento técnico e científico que, tornando mais complexas as tarefas humanas, obriga o homem a planejar e manter sob controle as forças que ele próprio desencadeou a fim de não vir a sofrer o infeliz destino de 'aprendiz de feiticeiro'. (Kühner, 1971, p. 17)

Dessa forma, o social passa a ser o valor principal, a força operativa que redimensiona boa parte da dramaturgia. Houve, por certo, um grande embate, pois a individualidade burguesa, mesmo decadente, ainda tinha sua força de atuação e não abriria tão fácil assim os espaços para um pensamento coletivo em que o social se tornasse o eixo principal da reflexão. Esta oposição, indivíduo x coletivo, vem desde as tragédias gregas, passando pelo Renascimento, porém o indivíduo esteve sempre acima do social, ou era o elemento de desestabilização do social. No Renascimento, por exemplo, o caos acontecia quando o líder, o rei, o príncipe, enlouquecia ou morria, advindo disso a desordem social, pois havia nestes elementos a presença de Deus, ou da Lei. Com sua morte ou loucura, tudo se desestabilizava. Para Maria Helena Kühner (1971, p. 18), o que houve no século XX foi uma inversão dessa ordem:

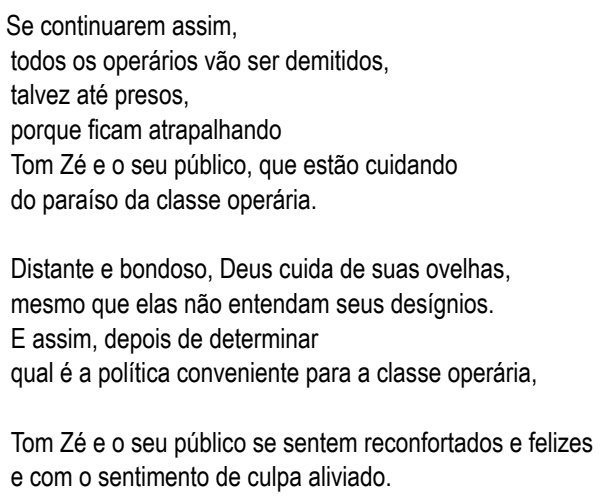

(Tom Zé. No jardim da política. CD. 1998). Disponível em http://www.tomze.com.br/, acesso em: 10 Mai. 2014

\footnotetext{
${ }^{4}$ Esse foi um conflito comum em muitas peças de dramaturgos ligados ao Teatro de Arena, como Gianfrancesco Guarnieri e Oduvaldo Viana Filho, sendo inclusive o eixo central de Eles não usam black-tie: o pai operário idealista versus um filho que quis priorizar a vida individual em detrimento do coletivo.
} 
"com a ascensão do social e a mundialização da vida, mundo e sociedade impõemse: o homem sente que não age, apenas é também coagido pelas 'circum - statias', pelo que está em torno e é diante dessas que sua individualidade tem que situar-se e equilibrar-se". Por fim, Maria Helena Kühner, em seu texto escrito no calor dos acontecimentos que marcaram o final da década de 1960, estabeleceu a força que o político teve no século XX:

\begin{abstract}
Nosso século é essencialmente político: político pela necessidade do homem de manter-se sujeito e agente da própria História; político pela ampliação de sentido e valor da "polis", da cidade ou comunidade, da exigência de um bem-comum que supera a estreiteza da ética individualista até então dominante; político pela mundialização da vida humana, que interliga as nações e seus destinos e torna a neutralidade impossível; político, enfim, pela própria natureza de suas maiores transformações, tanto em plano nacional quanto internacional: a correlação social-político-econômico é notória e os próprios fatos acima assinalados tem seu paralelo político nas lutas de classes e na crescente tentativa de quebra do colonialismo, quer estritamente político, quer o econômico, que busca se disfarçar até em já desmoralizados programas de "ajudas" e "investimentos". Essa inserção do político, ou do político-social, se manifesta cada vez mais na temática, mesmo em autores não comprometidos ideologicamente com alguma corrente ou diretriz política. (Kühner, 1971, p. 22)
\end{abstract}

À parte o tom grandiloquente e os erros ou acertos de sua análise vista mais de 40 anos depois, Maria Helena condensa muito de como se pensava no período, além de colocar em cheque a ideia de que só valeria um engajamento militante. A pesquisadora também estava embarcada na barca de Camus ${ }^{5}$, ou seja, não havia como não ser engajado nesse período, o político pairava em tudo, mesmo autores que propunham o absurdo, a crueldade, o teatro pobre ou o experimentalismo de toda ordem poderiam até ter a angústia subsistindo "como eixo central", mas havia também "a tentativa de localizar suas causas, atitude que traz sempre consigo, implícita ou explicita, uma ideia de denúncia que é também teatro político" [grifo da autora] (Kühner, 1971, p. 23). A brasileira também partilhava do mesmo ponto de vista de Bernard Dort (1971 p. 271), que já questionava onde estaria esse grande teatro de participação política. $O$ fato é que no século XX, principalmente a partir dos anos de 1920/1930, o estatuto do teatro como meio de expressão se modificou profundamente diante do surgimento de outros meios de expressão, sobretudo o cinema, o rádio e a televisão. Por outro lado, tanto o nazismo quanto o fascismo se utilizaram do teatro para celebrar uma unidade nacional que esteve longe de ser revolucionária. Nas palavras de Dort (1971, p. 272) a teatralização da vida política que se produzia então provocou uma suspeita em relação ao teatro de massa e de seu formidável poder de mistificação.

Mais distanciado pelo tempo do que Kühner ou Dort, Jacques Rancière (2012, p. 66) pensa nos paradoxos da arte política e nas diversas tentativas contemporâneas de repolitizar a arte. Para ele, existem três lógicas da eficácia da arte: "a lógica representativa que quer produzir efeitos pelas representações, a lógica estética que produz efeitos pela suspensão dos fins representativos e a lógica ética, que quer que

\footnotetext{
${ }^{5}$ Camus não pensava tanto no engajamento, mas sim que todos estavam embarcados no tempo, não haveria, portanto, maneira de sair, de ausentar-se das questões políticas e sociais. "Tout artiste aujourd'hui est embarqué dans la galère de son temps. II doit s'y résigner, même s'il juge que cette galère sent le hareng, que les gardes-chiourme y sont vraiment trop nombreux et que, de surcroît, le cap est mal pris. Nous sommes en pleine mer. L'artiste, comme les autres, doit ramer à son tour, sans mourir, s'il le peut, c'est-à-dire en continuant de vivre et de créer." (Camus, 1957)
} 
as formas de arte e as formas políticas se identifiquem diretamente umas com as outras". O fato é que o modelo mimético, base da primeira lógica, já tinha sido questionado por Rousseau, que estabeleceu aquilo que Rancière $(2012$, p. 56) chamou de modelo arquiético, ou seja, "no sentido de que os pensamentos já não são objetos de lições dadas por corpos ou imagens representados, mas estão diretamente encarnados em costumes, em modos de ser da comunidade". Esses dois modelos reverberam muito no século $X X$ : o modelo mimético não está mais tão presente, mas a lógica causal que lhe subjaz ainda é vigente: "o que vemos são os signos sensíveis de certo estado, dispostos pela vontade de um autor. Reconhecer esses signos é empenhar-se em certa leitura de nosso mundo." O modelo arquiético não deixou de acompanhar a modernidade, pois agiu "como pensamento de uma arte que se tornou forma de vida". No século XX teve seus melhores e maiores momentos nas ideias de obra de arte total, o coro do povo em ato, o futurismo e sua sinfonia, a força construtivista dada ao mundo mecânico (Rancière, 2012, p. 56).

Diante da polaridade entre aquilo que Rancière chama de pedagogia da mediação representativa versus pedagogia da imediatez ética - polaridade que ainda define o círculo no qual está ainda hoje encerrada boa parte da reflexão da arte - o filósofo francês pensa uma terceira forma de eficácia da arte, obscurecida pela polaridade das últimas duas. Trata-se da eficácia estética. A eficácia estética é paradoxal, pois "é a eficácia da própria separação, da descontinuidade entre as formas sensíveis da produção artística e as formas sensíveis através das quais os espectadores, os leitores ou os ouvintes se apropriam desta" (Rancière, 2012, p. 56). Rancière (2012, p. 58-59) trabalha com a ideia de que, em oposição ao regime de mediação representativa e imediatez ética, existe o "regime estético da arte", assim a "eficácia estética significa propriamente a eficácia da suspensão de qualquer relação direta entre a produção das formas de arte e a produção de um efeito determinado sobre um público determinado" A ruptura estética instalou uma singular forma de eficácia, que é a de uma desconexão, de uma ruptura nas relações entre "as produções das habilidades artísticas e dos fins sociais definidos, entre formas sensíveis, significações que podem nelas ser lidas e efeitos que podem produzir". É a eficácia de um dissenso. Que é o "conflito de vários regimes de sensorialidade". Dessa forma, a arte, no regime da separação estética, acaba por tocar na política, pois o dissenso está no cerne da política. Assim, arte e política tem a ver uma com a outra como formas de dissenso, "operações de reconfiguração da experiência comum do sensível" (Rancière, 2012, p. 63).

Estabelecendo as três lógicas, Rancière (2012, p. 66) diz que "a tradição da arte crítica quis articular essas três lógicas numa mesma fórmula. Tentou produzir o efeito ético de mobilização das energias encerrando os efeitos da distância estética na continuidade da relação representativa." Ele cita o distanciamento proposto por Brecht como um exemplo dessa tentativa. De certa forma, devido à forte presença dos conceitos brechtianos no teatro brasileiro nos anos 60, podemos ver também uma tentativa de conciliar as três lógicas, mas também um predomínio da lógica éti$c a$, que tem a ver com o ethos da comunidade, o modo de ser do coletivo, que escapa da esfera individualizada. A arte, na lógica ética, seria tomada em função de suas verdades e dos efeitos que produzem na forma de ser dos indivíduos. Antevemos tal 
lógica, por exemplo, nas ideias de Maria Helena Kühner; nessa ideia de que autores não comprometidos politicamente tinham algo político a dizer. A arte cumpriria seu destino social e político e, para muitos, suplantaria os valores estéticos.

Anterior a todos os pensadores citados acima, Walter Benjamin (1985, p. 121) também foi bastante crítico em relação a esse tipo de dicotomia: "por um lado devemos exigir que o autor siga a tendência correta, e por outro lado tempos direito de exigir que sua produção seja de boa qualidade". Trata-se de uma fórmula insuficiente, pois não há possibilidade de se conhecer a relação entre tendência e qualidade. A partir dessa constatação, Walter Benjamin adere ao pensamento de que uma obra justa pode ser caracterizada pelas demais qualidades inerentes à obra. A prova que Benjamin oferece sobre como a natureza desse tipo de obra é mais verdadeira do que aquela que é apenas justa, mas destituída de qualquer outro tipo de valor, é sobretudo literária. O conceito de tendência seria "um instrumento inteiramente inadequado para a crítica literária politicamente orientada", diz Benjamin (1985, p. 121), que defende a tese de que a tendência de uma obra literária só pode ser correta, sob o ponto de vista político, se for também correta do ponto de vista literário. Assim, “a tendência politicamente correta inclui uma tendência literária", sendo que é apenas a tendência literária, explicita ou implícita na tendência política correta, que determina a qualidade da obra. É possível pensar que a qualidade literária venha daquela porção dionisíaca que Benjamin viu no surrealismo, em seu ensaio "O surrealismo - o último instantâneo de inteligência europeia", texto no qual inverteu o primado da política sobre a literatura, aqui tratada como uma potência também revolucionária cuja tarefa mais autêntica seria "mobilizar para a revolução as energias da embriaguez" (Benjamin, 1985, p. 25-32). Os surrealistas seriam revolucionários porque pressentiram "energias revolucionárias" que transpareciam no "antiquado". Assim, nas coisas que começavam a se extinguir: as construções de ferro, as primeiras fábricas, as velhas fotografias, naquilo que tinha saído de moda, os surrealistas viam "de que modo a miséria, não somente a social como a arquitetônica, a miséria dos interiores, as coisas escravizadas e escravizantes, transformaram-se em niilismo revolucionário" (Benja$\min , 1985$, p. 25).

O teatro seria um espaço onde se podem manifestar as impossibilidades da realidade, onde o trabalhar com essa perspectiva é dar vazão ao político, é fazer com que o político assuma sua força de enfrentamento, de transformação, não no sentido utópico de uma sociedade completamente justa, ou sem classes, mas a percepção de que há outras continuidades além das estabelecidas ${ }^{6}$. Tornar a realidade impossível seria negá-la? Ou, ao contrário, lançá-la num campo em que ela pudesse existir de forma plena. Somente na impossibilidade é que a realidade faria sentido. Pirandello acreditava que a vida, por ser um fato, não precisava ser plausível; que a plausibilida-

\footnotetext{
${ }^{6}$ Um exemplo disso pode ser percebido na recente história brasileira. Tais ideias estavam sendo minadas pelo estado ditatorial e censor, bem como por toda uma outra gama de possibilidades estéticas e políticas que se fortaleciam no teatro, sobretudo numa levada antiburguesa, que se opunha à aristocracia ruralista e à pequena burguesia urbana, ambas decadentes, além de também assumir o tom anti-imperialista (Kühner, 1971, p. 38). Se o cenário ditatorial era perturbador, a resposta teatral, pelo menos nos primeiros anos, foi justamente apostar em novas trincheiras subversivas. Duas das apostas mais significativas vêm de Millôr Fernandes e Flávio Rangel: as peças 0 homem do princípio ao fim e Liberdade, Liberdade, montagens que fizeram grande sucesso e que tem como estrutura a colagem de trechos de outras peças, romances, poemas. Além disso, uma das montagens mais revolucionárias do período foi $O$ rei da vela, peça de Oswald de Andrade, encenada pelo Teatro Oficina, que carnavalizou a níveis inesperados a farsa tragicômica do modernista. Impondo ao teatro brasileiro um processo de radicalização nunca visto anteriormente, sobretudo por levar a política a outro nível, diferente do engajamento ou do didatismo de cunho marxista. 0 rei da vela propunha que o caos dionisíaco tomasse conta dos corpos, das mentes, da vida como um todo. Assim, o Teatro Oficina levava ao limite a frase de Heiner Müller: "a tarefa da arte é tornar a realidade impossivel".
} 
de era uma necessidade sine qua non da ficção. Dessa forma, o dramaturgo italiano acreditava que ver uma cena no palco era muito mais agudo e transformador que a memória do fato acontecido (apud Bentley, 1969, p. 161). Aqui, podemos pensar novamente em Rancière $(2012$, p. 64) e sua ideia de dissenso, na qual ele propõe que a política da arte seja um entrelaçamento de lógicas heterogêneas, ou seja, há em primeiro lugar "o efeito, no campo político, das formas de estruturação da experiência sensível próprias a um regime de arte", o que se pode chamar de política da estética, algo que se constitui de espaços neutralizados, da perda da função e destinação das obras, do anonimato dos destinatários das obras, "todas essas propriedades definem o domínio da arte como domínio de uma forma de experiência própria, separada das outras formas de conexão com o sensível." Diante disso, como agem os artistas? Buscam estratégias que pretendem mudar aquilo que é visível e enunciável, ou seja, "mostram o que não era visto, mostrar de outro jeito o que não era facilmente visto, correlacionar o que não estava correlacionado, com o objetivo de produzir rupturas no tecido sensível das percepções e na dinâmica dos afetos". Eis o trabalho da ficção, o trabalho de realizar dissensos, algo que muda os modos e as formas de enunciação e de apresentação do sensível, "mudando quadros, escalas ou ritmos, construindo relações novas entre a aparência e a realidade, o singular e o comum, o visível e sua significação" (Rancière, 2012, p. 64). Trata-se de uma mudança, da criação de espaços, ambientes, de uma "paisagem inédita no visível", diferente da política, que "consiste na produção de sujeitos que dão voz aos anônimos, a política própria à arte no regime estético consiste na elaboração de um mundo sensível dos anônimos, dos modos do isso e do eu, do qual emergem os mundos próprios do nós político" (Rancière, 2012 , p. 65). Talvez seja por isso que a arte, e mais especificamente o teatro, sejam tão aterradores e subversivos para os sistemas ditatoriais: porque o teatro foca, sublinha o que é notável, o que é extraordinário, não como mimesis, ou representação do real, mas como essa elaboração do mundo sensível do anônimo. Especificamente sobre o poder do teatro, Bentley afirma que

A palavra dramaturgia sugere um arsenal cheio de esquemas destinados a criar ordem a partir do caso de fatos e ficção. Quanto mais compreensível uma coisa é, tanto mais vivida se torna. O incontrolável é colocado sob controle, as trevas se tornam claras. Não é difícil perceber aquilo que as partes interessadas têm a recear. Se tiverem consciência pesada, terão a recear o dies irae, quando a verdade surgir de repente e chegar o momento da punição dos malfeitores. Eles terão a recear o contorno de linhas nítidas que uma peça pode traçar em volta da verdade; eles terão a recear o poder de convicção que uma peça pode possuir. $(1969$, p. 161)

Dessa forma, o teatro seria essa concentração que estabelece uma luz, um foco, sob aquilo que é disperso, rápido demais. Bentley (p. 163) afirma, ironicamente, que não seria necessário um teatro da crueldade porque o teatro em si já é cruel. E essa crueldade está em agredir o agressor, em subverter os golpes, as ditaduras, os sistemas de dominação e exclusão. Não apenas porque o teatro é cruel, mas porque ele também tem entradas e saídas para a política, ou aquilo que Lehmann conceitua como "interrupção":

Esse movimento da pausa e da interrupção pode ser experimentado quando se 
está andando e se pode, por um momento, suspender o ato de andar e pensar sobre o que é esse elemento. Você interioriza o andar e, com isso, se distancia dele. Esse conceito da interrupção e da cesura é muito simples, mas tem muitas significações. Ele não se relaciona somente com essa percepção do sensível, com a surpresa e com a coisa inesperada. Ele se relaciona também com nossos conceitos e com nosso pensamento. Pode funcionar como um choque que fazendo com que a realidade se torne, de repente, uma coisa não mais possível e que nos faça pensar a respeito disso. (Lehmann, 2008, p. 238)

Analisando o teatro da crueldade, proposto por Artaud, Lehmann (2008, p. 243) fala sobre como o artista se sente frente ao mundo que estamos vivendo. Trata-se de um colocar-se, de um estar em frente ao perigo. "E esse perigo é o perigo de perder a fala. Não ter a possibilidade da fala, não ter a possibilidade de intervenção ou de ser ouvido numa sociedade como essa." Esse perigo de ficar mudo, de não conseguir intervir, é muito forte, e motiva os artistas numa busca contrária, numa busca por saídas, posicionamentos éticos e estéticos que minem o perigo do silêncio, da indiferença7.

Desde muito tempo os artistas vêm trabalhando no sentido de uma transformação social, vem colocando a arte como um instrumento de mudança, conscientização, um instrumento revolucionário por excelência. Para muitos, a arte, a luta política e a revolução irmanam-se no enfrentamento dos sistemas totalitários, dos sistemas injustos que predominam nas sociedades. Artistas em geral agem como vozes de ruptura da ordem, cuja força, não raro, é sufocada pela censura ${ }^{8}$. E sendo o teatro uma arte de grande aproximação com o público, ele sempre obteve sobre si o olhar das inquisições, das censuras, enfim, foi vítima de controles bastante acentuados.

\section{Um olhar sobre engajamento e liberdade no teatro brasileiro}

Em julho de 1968, a Editora Civilização Brasileira lançava aquele que viria a ser um dos principais documentos sobre o teatro brasileiro no período: a Revista civilização brasileira - Caderno especial 2 - Teatro e realidade brasileira. Entre os diversos ensaios e entrevistas constantes na publicação, o ensaio inicial, intitulado "O engajamento é uma prática de Liberdade", era de autoria de Dias Gomes, já na época um proeminente dramaturgo e escritor. Em seu texto, escrito ainda ao calor das lutas sociais e pré-AI5, Dias Gomes ressalta que foi "no teatro que se fez a primeira de-

\footnotetext{
${ }^{7}$ Pensando pelo viés do dissenso, causado pela ruptura estética entre a lógica representativa e a lógica ética, Rancière (2012, p. 66-67) questiona criticamente essas tentativas dos artistas em buscar um lugar, sobretudo quando a arte crítica tentou articular as lógicas da eficácia representativa, da eficácia ética e da eficácia estética: "não se passa da visão de um espetáculo à compreensão do mundo e da compreensão intelectual a uma decisão de ação". O que se tem é a passagem de um mundo sensível para outro mundo sensível, o que funciona são as dissociaçães: "ruptura de uma relação entre sentido e sentido, entre um mundo visível, um modo de afeição, um regime de interpretação e um espaço de possibilidades." Pensando sobre a arte do século XXI, Rancière se questiona sobre o que aconteceu com a arte crítica na era do consenso. Nesse contexto economicamente globalizado que impõe a cada nação "adaptar-se a um dado sobre o qual ela não tem poder, adaptar a ele seu mercado de trabalho e suas formas de proteção social". Dessa forma, se desvanece a luta contra o sistema capitalista, luta que sustentava a arte crítica. Estamos num período em que o capitalismo é "equiparado a uma fatalidade da civilização moderna, da sociedade democrática ou do indivíduo de massa". Nos dias de hoje, um dos grandes problemas da política da arte é a tentativa de atacar o sistema capitalista com técnicas que pouco variaram nas últimas décadas: "pretende-se denunciar o reinado da mercadoria, de seus ícones ideais e de seus detritos sórdidos por meio de estratégias bem surradas", tais como filmes publicitários, personagens da cultura pop transformados em obras de arte, mostras fotográficas que se assemelham aos panfletos publicitários, instalações gigantescas com utensílios domésticos etc. Tais obras continuam ocupando as galerias e os museus numa tentativa de denúncia do mercado, do poder da mercadoria, do consumismo. "Mas como ninguém em nosso mundo é tão distraído que seja preciso chamar-lhe a atenção, o mecanismo gira em torno de si mesmo e se vale da própria indecidibilidade de seu dispositivo" (Rancière, 2012, p. 68). Diante disso, Rancière atesta que "o modelo crítico da arte tende, assim, à autoanulação".

${ }^{8}$ Barthes, em Aula, (1980, p. 17), estabeleceu o engajamento na literatura e não no artista: "As forças de liberdade que residem na literatura não dependem da pessoa civil, do engajamento político do escritor que, afinal, é apenas um "senhor" entre outros, nem mesmo do conteúdo doutrinal de sua obra, mas do trabalho de deslocamento que ele exerce sobre a língua: desse ponto de vista, Céline é tão importante quanto Hugo, Chateaubriand tanto quanto Zola. O que tento visar aqui é uma responsabilidade da forma: mas essa responsabilidade não pode ser avaliada em termos ideológicos e por isso as ciências da ideologia sempre tiveram tão pouco domínio sobre ela.". Este é um olhar mais estruturalista que se direciona ao texto.
} 
núncia organizada contra o estado de coisas criado pelo golpe militar direitista" (CB, p. 7). Muito disso se deve à força agregadora do teatro, também destacada por Dias Gomes:

Em primeiro lugar, devemos levar em conta o caráter do ato político-social inerente a toda representação teatral. A convocação de um grupo de pessoas para assistir outro grupo de pessoas na recriação de um aspecto da vida humana, é um ato social. E político, pois a simples escolha desse aspecto da vida humana, do tema apresentado, leva o autor a uma tomada de posição. Mesmo quando ele não tem consciência disso. (1968, p. 10)

Nos anos posteriores ao golpe militar de 1964, houve uma forte união das gentes do teatro, incluindo suas áreas de cunho conservador, que se juntaram aos setores mais progressistas, saindo da dimensão de seus interesses individuais e financeiros, enfrentando diretamente as forças estabelecidas pelo golpe. Essa união era direcionada a um público que, para Dias Gomes, aceitava e aplaudia o teatro de esquerda, que não tinha características antiburguesas muito estabelecidas, mas que arriscava propostas socialistas sobre o palco. O público aceitava até mesmo ser agredido por montagens cujo predicado substancial seria a transgressão, como é o caso de Roda Viva, peça de Chico Buarque com direção de José Celso Martinez Corrêa. O público era formado majoritariamente por estudantes e, naquele momento, estimulava economicamente e moralmente as experiências mais radicais de afastamento de modelos estratificados de teatro. Peças como Arena conta Tiradentes, O rei da vela ou Roda viva dificilmente se realizariam se não tivessem um público ávido por novidades. Se por um lado, havia uma gente apoiando, por outro as pressões políticas jogavam o teatro no terreno da censura, da perseguição. Dias Gomes também destaca a inexatidão de critérios dos censores:

Quanto às pressões políticas, elas são exercidas através de uma censura policial e inepta, que procede de maneira imprevisível. Sua falta de critérios definitivos, sua absoluta incapacidade intelectual e sua sujeição às oscilações do jogo político interno, levam esse órgão opressor a uma atuação pendular que vai de um liberalismo contraditório ao reacionarismo mais ridículo. (Gomes, 1968, p. 12)

O dramaturgo fundamenta teoricamente suas ideias de engajamento a partir dos conceitos de um outro existencialista, Paul-Louis Landsberg, que publicou na revista Esprit, em 1937, o ensaio "Reflexões sobre o engajamento pessoal" 9 . Landsberg propõe o engajamento como condição essencial para aquilo que ele chama de qualidade humana:

O que denominamos engajamento é o assumir concreto da responsabilidade de uma obra a ser realizada no futuro, de uma diretriz definida para o esforço que dirigimos à formação do futuro humano. Consequentemente, é o engajamento que realiza nossa historicidade humana e querer subtrair-se a ele representa, em geral, a destruição do próprio progresso de nossa qualidade humana. (Landsberg, 1968, p. 22)

Para Landsberg, é preciso encarar essa responsabilidade de que o engajamento é aquilo que realiza a historicidade. $O$ homem está preso à sua responsabilidade, reconhece o fardo de carregá-la, tem desejos de liberdade, mas isso é uma ilusão 
impossível, pois não pode negar a historicidade e também não pode se abrigar na "inconsciência do animal". O homem pode até refugiar-se momentaneamente numa espécie de alienação infantil, ou mesmo tentar projetar-se para o passado, ou para um lugar mais primitivo, no entanto tudo é passageiro, pois "a historicidade é quase sempre dolorosa, mas não temos o direito, nem a possibilidade, de nos recusarmos a sua realização em nós" (Landsberg, 1968, p. 23). É com a perspectiva de mudança do futuro que Landsberg trabalha. Personalista, ele partilhava as ideias de um existencialismo cristão, que tinha em comum com o existencialismo ateísta de Sartre o fato de ser o homem a questão principal da existência, defendia a ideia de que a vida não se resume a fatores meramente materialistas. Assim, no embate entre o futuro individual e o futuro coletivo o engajamento só é real se houver participação nesse jogo contraditório. Não se trata de uma opção pelo coletivo, nem pelo individual, pois o personalismo ${ }^{10}$ seguido por Landsberg advém de uma "doutrina ético-política que enfatiza o valor absoluto da pessoa e seus laços de solidariedade com as outras pessoas, em oposição ao coletivismo (que tende a ver na pessoa nada mais que uma unidade numérica), e ao individualismo (que tende a enfraquecer os laços de solidariedade entre as pessoas)", conforme Nicola Abbagnano (1998, p. 759). Por isso, é preciso sempre assumir uma causa imperfeita, porque a escolha não se dá no mundo das ideologias abstratas, mas sim no mundo dos fatos, das forças e dos movimentos reais que, do passado e do presente, vem conduzir "a região das possibilidades do futuro". Para Landsberg (1968, p. 24), "o valor de um engajamento consiste, em grande parte, na coexistência e na tensão produtiva entre a imperfeição da causa e o caráter definitivo do engajamento".

O engajamento é um ato livre e total e estaria acima de qualquer operação intelectual ou da simples militância de um grupo. Landsberg segue sua explanação colocando o engajamento num campo mais filosófico, mais profundo do que o mero aceite a uma ideologia, a um princípio político ou econômico que venha assumir o poder. Para ele,

\begin{abstract}
é importante, antes de mais nada, defender o ato de engajar-se contra o juízo, que se diz neutro, da parte de uma falsa nobreza intelectual e distinguir, ao mesmo tempo, este ato de um 'alistamento' sem espírito e sem consciência. A qualidade específica do ato que buscamos caracterizar o torna, simultaneamente, um ato total e um ato livre: ato total, porque não se trata de uma atividade da inteligência, agindo isoladamente ou de atividade exclusiva da vontade, pois o engajamento é obra do homem integral, no qual a inteligência e a vontade se confundem. Ato livre, não por participar de uma liberdade formal de arbítrio, mas por traduzir uma decisão da pessoa, que toma consciência de sua responsabilidade específica e realiza sua formação positiva como pessoa. [...] O homem engajado permanece um homem livre, isto é, que se liberta permanentemente pela humanização. (Landsberg, 1968, p. 24)
\end{abstract}

A liberdade não seria, portanto, um estado, mas um ato e, ao engajar-se, o artista exerce a sua liberdade de forma contínua e integral tanto como artista quanto como homem, aspectos indissolúveis da mesma pessoa. A liberdade sempre desapa-

\footnotetext{
${ }^{9}$ Dias Gomes cita o ensaio publicado na Revista Paz e Terra n 5 , publicada em 1967. 0 ensaio também foi publicado no livro de Paul-Louis Landsberg, 0 sentido da ação, em 1968, também pela editora Paz e Terra. Utilizaremos essa última publicação como referência.

10 “Personalismo Francés, doctrina defensora de un socialismo cristiano dedicada a promover el activismo social y la responsabilidad personal. Constituye, asimismo, la base teórica del movimiento de trabajadores cristianos, Esprit, puesto en marcha en la década de 1930 por
} 
rece quando ela não vem a ser. Retomando esses princípios, Dias Gomes (1968, p. 16) defende a ideia de que conhecimento e engajamento não são polos que se repelem. O engajamento não seria um obstáculo na busca da verdade, mas uma condição que ajudaria o artista, o intelectual a conhecer a verdade "em toda a sua plenitude e expressá-la esteticamente." O que predominava no período era um pensamento que estabelecia a vida, ou a "aventura humana" no dizer de Dias Gomes, como algo muito maior do que a soma dos acontecimentos, e o artista não poderia contemplar e constatar essa aventura pela neutralidade, mas sim pelo comprometimento. Ainda amparando-se em Paul-Louis Landsberg, Dias Gomes critica o intelectualismo puro, que tenta separar a inteligência criadora da personalidade total. Propor essa separação, estabelecer que o artista deva ser apenas um espectador impessoal dos fatos, seria um risco para que forças cegas, como a do fascismo, do nazismo ou da ditadura, ganhassem mais força. Landsberg $(1968$, p. 28$)$ é bastante assertivo em tempos préSegunda Grande Guerra: "a falsa superioridade dos que se mantém fora de tudo se tornou uma verdadeira peste em nosso mundo e a tolerância hipócrita dos que se contentam com explicar tudo paralisa o espírito ocidental". O que se deseja aqui é o engajamento efetivo, real, aquele que se compromete com a liberdade e com o conhecimento, pois o engajamento em uma causa histórica tem que encarar determinados valores e isso não será um obstáculo ao conhecimento, mas uma "necessidade da vida moral e um meio indispensável ao próprio conhecimento" (Gomes, 1968, p. 17), ou seja, o artista não poderia se eximir de engajar-se, de estar presente na luta, pois era isso que determinava o que era um verdadeiro intelectual.

Dias Gomes (1968, p. 17), tendo por base o idealismo engajado de Landsberg, vai além na defesa do engajamento como condição sine qua non de todo artista: "o não-engajamento priva o artista de um dado importante: a percepção dos valores, sem o que toda verdade é incompleta." Assim, para um dos principais dramaturgos brasileiros, os novos autores entendiam o teatro como uma forma de conhecimento da realidade e passaram a desempenhar um papel decisivo "na formação da consciência de que a liberdade é essencial à arte". O teatro, portanto, seria uma forma de conhecimento que, se produzido de forma honesta, levaria, inevitavelmente, ao engajamento, e neste a liberdade se confundiria com o próprio conhecimento, tornando-se imprescindível.

Landsberg é bastante assertivo ao discorrer sobre um equilíbrio na busca da liberdade:

Nós não temos que escolher entre o "clérigo" de Benda, que aplica ideias "eternas" na mudança da realidade, o espectador "inteligente", para o qual todos os valores não passam de ilusões, e o partidário fanático que aspira à vitória de seus valores tanto mais fanaticamente quanto maior ou menor sua consciência de têlos estabelecido arbitrariamente. $\mathrm{O}$ homem do engajamento pessoal não deve se assemelhar a nenhuma dessas caricaturas. (Landsberg, 1969, p. 34)

\footnotetext{
Emmanuel Mounier (1905-1950), activista y filósofo cristiano. Influido tanto por el existencialismo religioso de Kierkegaard como por la acción social radical propugnada por Marx y adoptando, al menos en parte, las directrices presentes en los primeros trabajos de Charles Péguy, este movimiento se opuso durante las décadas de 1930 y 1940 al fascismo demandando la solidaridad entre los trabajadores. También exigió un tratamiento más humanitario de las colonias francesas. Esta doctrina pugnaba por un socialismo cristiano independiente de los grupos cristianos más conservadores e independiente también de los sindicatos y del Partido Comunista. La obra más conocida en este terreno es Personalismo, de Mounier. La revista Esprit ha venido publicando con regularidad contribuciones de líderes frances y de pensadores de talla internacional. Filósofos cristianos del reconocimiento de Henry Duméry, Marcel, Maritain y Ricoeur fueron atraídos en su día por este movimiento." (BIEN, Joseph. Personalismo Francés. In: AUDI, Robert (ed.). Diccionario Akal de filosofia. Madrid: Akal, 2004 p. 761).
} 
Uma década antes do texto de Landsberg, Julien Benda escreveu La trahison des clercs. Benda foi um pensador bastante contraditório, pois conseguiu ser rotulado como reacionário de esquerda e ser considerado também de direita. Era assumidamente antimoderno, e propunha o "não-engajamento" do escritor, ou seja, para Benda, o compromisso do intelectual era com os valores eternos, com aquilo que transcendia a vida cotidiana e que se punha sempre como metas a serem conquistadas durante toda a história. O compromisso dos intelectuais deveria ser com a Liberdade, a Justiça, a Razão, em letra maiúscula como cabe aos valores eternos. Não se poderia colocar acima desses interesses qualquer valor mais materialista, mais prático ou cotidiano, pois isso seria trair o compromisso. Para Benda, quando um intelectual assume a imposição realista que a sociedade the impunha e, ainda mais, quando o intelectual gosta ou "exerce com alegria" esse realismo, esse apego ao cotidiano percebe-se "então, que estamos diante de algo bem diferente de uma função cujo exercício é contrariado por acontecimentos de um momento: estamos diante de um cataclismo das noções morais entre aqueles que educam o mundo" (Benda, 1999, p. 76).

No seu Dicionário de Política, Norberto Bobbio (1998, p. 300) diz que Julien Benda "defendia a teoria de que o intelectual tinha de ser, como no século XVIII, um mau patriota", ou seja, não era pelo engajamento político que os intelectuais lutariam contra as forças opressoras, mas sim se assumindo cada vez mais como pensadores metafísicos. Se Landsberg foi firme na premissa de que não se deve escolher entre o platonismo exagerado de Benda e o partidarismo fanático muito em voga no período, Sartre é um pouco mais ameno e parte de um questionamento:

Engajado em que? Perguntarão. Defender a liberdade, afirmação precipitada. Trata-se de tornar-se o guardião dos valores ideais, como o "intelectual" de Benda antes da traição, ou será que é a liberdade concreta e cotidiana que é preciso proteger, tomando partido nas lutas políticas e sociais? (Sartre, 2004, p. 53)

A resposta sartriana foi tentar responder a pergunta "para quem se escreve?", e, ao respondê-la, Sartre se encaminha para a proteção da liberdade concreta e cotidiana, pois se o escritor incita o leitor com a liberdade isso não é apenas "uma pura consciência abstrata de ser livre", porque, em consenso com Landsberg, Sartre não pensa a liberdade como algo ou estado isolado, fechado em si mesmo, ao qual não se pode predicar qualquer atributo, mas algo que "se conquista numa situação histórica" (Sartre, 2004, p. 63). Essa escolha de Sartre por encampar um engajamento efetivo chegou a muitos escritores e intelectuais como um hino ${ }^{11}$. Ao tratar a presença do homem no mundo como tema fundamental da literatura, Sartre percebe que

enquanto o público virtual permanecia como um mar sombrio em torno da pequena praia luminosa do público real, o escritor corria o risco de confundir os interesses e as preocupações do homem com os de um pequeno grupo mais favorecido. Mas se o público se identificasse com o universal concreto, é realmente sobre a totalidade humana que o escritor deveria escrever. Não sobre o homem abstrato de todas as épocas e para um leitor sem data, mas sobre todo o homem de sua época e para os seus contemporâneos. Em consequência, a antinomia literária entre a subjetividade lírica e o testemunho objetivo ficaria superada. Engajado na mesma aventura que os seus leitores e situado, como eles, numa coletividade sem 
divisões, o escritor, ao falar deles, falaria de si mesmo e, ao falar de si mesmo, falaria deles. (Sartre, 2004, p. 118)

Na utopia sartriana, não existem temas impostos, não existem poucos leitores. $A$ liberdade será o canal do diálogo, o escritor ao falar de si fala de todos e para todos. Não haveria mais o orgulho aristocrático de ser escritor. Tal atividade não seria mais uma diferença, geralmente superior, mas uma experiência de igualdade:

[...] sua situação seria universal, ele exprimiria as esperanças e as cóleras de todos os homens e, assim exprimiria a si mesmo por inteiro, isto é, não como criatura metafísica, à maneira do clérigo medieval, nem como animal psicológico, à moda dos nossos clássicos, nem mesmo como entidade social, mas como uma totalidade que emerge do mundo no vazio e encerra em si todas essas estruturas na unidade indissolúvel da condição humana. (Sartre, 2004, p. 118)

Sartre propõe uma sociedade em que não haveria separação entre o temporal e o espiritual. Tal separação sempre correspondeu à alienação do homem e, por consequência, da literatura e da arte como um todo. Para Sartre, a literatura, por mais que tenha reivindicado categorias como o Belo, a Perfeição Divina, o Bem, o Verdadeiro, sempre esteve do lado dos opressores, seja como cão de guarda, seja como bobo da corte. Apenas quando a literatura puder "usufruir de sua essência", o escritor, livre de todas as prisões das classes, salões, prêmios, honrarias, festividades, hipocrisias do sistema literário, não será mais um "intelectual", e sim um homem entre os outros.

Essa diminuição da categoria, ou da importância, do artista é um passo bastante complexo, dado todo o jogo de vaidades que interferem no processo criativo e na construção do nome do escritor, de um ator e dos artistas em geral. Esse desapego, esse pertencimento à situação histórica, cujo cenário é de totalitarismo, de perseguição individual e violenta a qualquer voz que ouse um grito fora do tom, um salto fora do ritmo estabelecido, põe em cheque, muitas vezes, a capacidade que o autor tem de falar, de se manifestar. Entra aí todo um jogo de forças internas e externas que atuam no sentido do silêncio. O medo, os desaparecimentos, as prisões, as torturas, a censura inquisitória são lâminas sobrepassando a liberdade de expressão e a própria segurança física das pessoas que se envolvem, que se engajam em movimentos opositores.

Ainda pensando sob o viés de que o homem está condenado à liberdade, Sartre (2004, p. 51) diz que "a obra de arte, vista de qualquer ângulo, é um ato de confiança na liberdade dos homens. E uma vez que leitores e autor só reconhecem essa liberdade para exigir que ela se manifeste, a obra pode se definir como uma apresentação imaginária do mundo na medida em que exige a liberdade humana". Para Sartre, não há escolha:

Pois não se pode exigir de mim, no momento em que percebo que minha liberda-

Sartre foi um dos pensadores mais lidos no Brasil nos anos de 1960, e muitas de suas peças foram encenadas por aqui; seu pensamento encontrou eco na intelectualidade brasileira, como nesse depoimento de José Celso Martinez Corrêa: "Eu já lia Sartre e já conseguia localizar nos textos dele certos pontos de identificação com a gente. Por exemplo, a minha geração sentia que tinha que se virar por ela mesma. Aí entrava a noção sartriana de "liberdade", de que não tem desculpa, de que você tem que se atirar nas coisas mesmo. Não tem pai, não tem mãe, não tem ditadura que lhe justifique, não tem opressão, não tem nada!" STAAL, A. E. C. (org.). Primeiro ato - cadernos, depoimentos, (1958 - 1974). São Paulo: 34, 1998) Esse chamado à ação, ao tomar para si a liberdade, também fazia parte das leituras de Hilda Hilst. O escrever dramaturgia tornou-se, por assim dizer, essa busca de amplitude maior para as ideias, de uma tentativa severa e grave de liberdade. Em uma pesquisa na sua biblioteca, percebe-se diversos livros de Sartre na estante. 
de está indissoluvelmente ligada à de todos os outros homens, que eu a empregue para aprovar a servidão de alguns dentre eles. Assim, quer seja ensaísta, panfletário, satirista ou romancista, quer fale somente das paixões individuais ou se lance contra o regime social, o escritor, homem livre que se dirige a homens livres, tem apenas o único tema: a liberdade. (2004, p. 51)

Trata-se do enfrentamento contínuo e continuado da responsabilidade de ser livre e de ter como único tema a liberdade. Inclusive, pode-se perceber que a premissa de Sartre (2004, p. 117) assemelha-se a do marxismo, mas não é uma profissão de fé marxista: "em suma, a literatura em ato só pode se igualar à sua essência plena numa sociedade sem classes". O sonho da sociedade sem classes, igualitária, predominava e contaminava diversos intelectuais do período, porém a arte que Sartre sonhava numa sociedade sem classes se afastava em muito das premissas rígidas do realismo socialista, já que o que contava aqui era a liberdade como um valor absoluto, concreto, e não uma liberdade dirigida, que exigiria que o escritor falasse apenas das benesses do regime socialista. Portanto, seguindo essa lógica, não há como escapar, escrever e atuar é sempre uma maneira de desejar a liberdade, seja qual for o motivo for pelo qual o escritor escreva, que o ator atue, seja qual a forma como ele começou, ele sempre será um escritor ou um artista engajado.

Assim, pensando nestas dicotomias que estão sempre em fluxo e refluxo, conforme demonstramos, não admitindo categorizações fáceis e estanques, que arriscamos retomar e o conceito de Rancière de "regime estético da arte" que não polariza categoricamente a arte em sendo ou política ou estética. A rigor, como se comprova com o exposto neste artigo, as dimensões híbridas das artes, em especial a dimensão do fazer teatral, se mostram cada vez mais presentes, conforme muito bem atestado por Lehmann em seu O Teatro Pós-Dramático. O século XX, muito por necessidade, ainda ofereceu uma distinção segura entre um suposto teatro político em confronto com um teatro estetizante. Do final do século $X X$ às duas primeiras décadas do século vigente, estas categorizações vêem sofrendo novos olhares que privilegiam suas dimensões artefactuais e ficcionais e, bem por isso, sua presença política e estética no mundo concreto em que ela passa a impor sua existência.

\section{Referências}

ABBAGNANO, Niccola. Dicionário de filosofia. São Paulo: Martins Fontes, 1998.

ARISTÓTELES. Poética; Organon; Política; Constituição de Atenas. Coleção Os Pensadores. São Paulo: Nova Cultural, 1999.

BENDA, Julien. A Traição dos Intelectuais. In: BASTOS, E. R. e REGO, W. L. Inte lectuais e política. A moralidade do compromisso. São Paulo: Olho d'água. 1999.

BIEN, Joseph. Personalismo Francés. In: AUDI, Robert (ed.). Diccionario Akal de filosofía. Madrid: Akal, 2004 p. 761. 
BOAL, Augusto. Hamlet e o filho do padeiro. Memórias imaginadas. Rio de Ja neiro: Record, 2000.

BOBBIO, Norberto. Dicionário de Política. Brasília: Editora UNB, 1998.

BENJAMIN, Walter. Magia e técnica, arte e política. 4aㅡ ed. Tradução Sergio Paulo Rouanet. São Paulo: Brasiliense, 1985.

BENTLEY, Eric. O teatro engajado. Rio de Janeiro: Zahar Editores, 1969.

CAMUS, Albert. L'Artise et son temps" - Conférence d'Albert Camus dans le grand amphithéâtre de l'Université d'Upsal le 14 décembre 1957. Disponível em “Les classics des sciences sociales - Université du Québec à Chicouttimi. Disponí vel em http://classiques.uqac.ca/classiques/camus_albert/discours_de_suede/ discours_de_suede_texte.html Acesso em: 13 abr. 2016.

DORT, Bernard. Théâtre Réel. Paris: Editions du Seuil, 1971.

GOMES, D. "O engajamento é uma prática de liberdade". In: Revista da Civili zação Brasileira. (Caderno especial n2) Teatro e realidade brasileira. Rio de Ja neiro: Civilização Brasileira. 1968

KÜHNER, Maria Helena. Teatro em tempo de síntese. Rio de Janeiro: Paz e Terra, 1971.

LANDSBERG, Paul-Louis. O sentido da ação. Rio de Janeiro: Paz e Terra, 1968.

LEHMANN, Hans-Thies. Escritura política no texto teatral. São Paulo: Perspecti va, 2009.

Cosac Naify, 2007.

O teatro pós-dramático. Tradução Pedro Süssekind. São Paulo:

PARANHOS, Adalberto. História, política e teatro em três atos. In: PARANHOS, Katia Rodrigues. História, teatro e política. São Paulo: Boitempo, 2012.

PLATÃO, A república. 8.ed. Lisboa: Fundação Calouste Gulbenkian, 1996.

RANCIÈRE, Jacques. O espectador emancipado. Tradução Ivone C. Benedetti. São Paulo: Martins Fontes, 2012.

REVISTA DA CIVILIZAÇÃO BRASILEIRA. (Caderno especial nํ) Teatro e realida de brasileira. Rio de Janeiro: Civilização Brasileira, 1968.

SARTRE, J. P. O que é a literatura? Tradução: Carlos Felipe Moisés. São Paulo: Ática, 2004. 
STAAL, A. E. C. (org). Primeiro ato - cadernos, depoimentos, (1958 - 1974). São Paulo: 34, 1998).

SZONDI, Peter. A teoria do drama moderno -1880 a 1950. São Paulo: Cosac $\&$ Naify, 2001.

ZÉ, Tom. No jardim da política. cd. 1998. Disponível em http://www.tomze.com. br/, acesso em 10 Mai. 2014.

Recebido em: 29/04/2016 Aprovado em: 05/07/2016 